\title{
DUNAIMYCINS, A NEW COMPLEX OF SPIROKETAL 24-MEMBERED MACROLIDES WITH IMMUNOSUPPRESSIVE ACTIVITY \\ I. TAXONOMY OF THE PRODUCING ORGANISMS, FERMENTATION AND ANTIMICROBIAL ACTIVITY
}

\author{
James P. Karwowski, Marianna Jackson, Mary L. Maus, William L. Kohl, \\ Patrick E. Humphrey and Pauline M. Tillis
}

\author{
Pharmaceutical Products Research and Development, Abbott Laboratories, \\ Abbott Park, Illinois 60064, U.S.A.
}

(Received for publication May 15, 1991)

\begin{abstract}
The dunaimycins are a new complex of spiroketal 24-membered macrolides discovered in the fermentation broth of two actinomycetes. Based on taxonomic studies these two cultures, which were isolated from soil, were identified as Streptomyces diastatochromogenes strains AB 1691Q-321 and $\mathrm{AB} 1711 \mathrm{~J}-452$. The dunaimycins possess both immunosuppressive and antimicrobial activity.
\end{abstract}

The dunaimycins are a new complex of compounds discovered in the fermentation broths of Streptomyces diastatochromogenes strains AB 1691Q-321 and AB 1711J-452. These compounds were discovered with a screen for antifungal activity. Additional testing showed that they had significant immunosuppressive effects. This paper describes the taxonomy of the producing microorganisms, the fermentation and the antibiotic activity of several members of the complex. The isolation, structural elucidation and immunosuppressive activity of the dunaimycins are described in accompanying publications $^{1,2)}$.

\section{Materials and Methods}

\section{Microorganisms}

Strain AB 1691Q-321 was isolated from soil collected at Parsberg, Germany. A subculture of the microorganism was deposited at the Northern Regional Research Center, United States Department of Agriculture, Peoria, Illinois, U.S.A. and assigned accession code NRRL 18716. Strain AB 1711 J-452 was obtained from soil collected on the banks of the Danube River near Belgrade, Yugoslavia. It was given accession code NRRL 18717 at the same repository. The bacteria and fungi used for bioassays were from the stock culture collection in our laboratory and from the ATCC.

\section{Taxonomic Studies}

Methods and media described by the International Streptomyces Project (ISP) ${ }^{3)}$ were used to determine most of the taxonomic characteristics of strains AB 1691Q-321 and AB 1711J-452. ATCC medium $172^{\dagger}$ and a dilute starch-yeast extract-salts (DSYS) agar ${ }^{4)}$ were added for morphological studies. Starch hydrolysis was determined by the method of Gordon et al. ${ }^{5}$, the test for $\mathrm{H}_{2} \mathrm{~S}$ production was according to SMIBERT and KRIEG $^{6)}$ and nitrate reduction was examined by KuTZNER's technique ${ }^{7)}$. Morphological observations were made after incubation at $28^{\circ} \mathrm{C}$ for 21 days. Utilization of carbon sources was determined after incubation at $28^{\circ} \mathrm{C}$ for 14 days. Color names were assigned to the mycelial and diffusible pigments on the basis of the Inter-Society Color Council-National Bureau of Standards (ISCC-NBS) Centroid Color

$\uparrow$ American Type Culture Collection. ATCC Media Handbook. First Ed., American Type Culture Collection, Rockville, 1984. 
Charts ${ }^{\dagger}$. Analysis of the whole-cell diaminopimelic acid isomer was done by the method of BECKER et al. ${ }^{8)}$.

\section{Fermentation Studies}

The inocula for antibiotic production by strains AB 1691Q-321 and AB 1711J-452 were initiated by the following procedure. Vegetative mycelium, stored at $-75^{\circ} \mathrm{C}$, was used at $0.4 \%$ to inoculate 2-liter Erlenmeyer flasks containing $600 \mathrm{ml}$ of medium. The seed medium consisted of glucose monohydrate $1.5 \%$, soy flour $1.5 \%$, yeast extract (Difco) $0.1 \%, \mathrm{NaCl} 0.1 \%$ and $\mathrm{CaCO}_{3} 0.1 \%$. This medium was prepared with distilled water and adjusted to $\mathrm{pH} 7$ before sterilization. The seed flasks were incubated for 72 hours at $28^{\circ} \mathrm{C}$ on a rotary shaker $(5.6 \mathrm{~cm}$ stroke) at $225 \mathrm{rpm}$.

The fermentation medium for strain AB 1691Q-321 consisted of starch (Staley Staclipse JUB) 3.0\%, molasses (Del Monte) 2.0\%, Lexein F-159 liquid peptone (Inolex) $2.0 \%$, whole yeast (Universal Foods) $0.5 \%, \mathrm{CaCO}_{3} 0.2 \%$ and $\mathrm{XFO}-371$ antifoam. The antifoam was added initially at $0.01 \%$ and then was available on demand. This medium was also prepared with distilled water and adjusted to $\mathrm{pH} 7$ before sterilization. Fermentation was carried out in a 150 -liter vessel containing 80 liters of medium. The fermenter was inoculated with 4 liters of seed flask growth. The temperature was controlled at $28^{\circ} \mathrm{C}$. The agitation rate was $250 \mathrm{rpm}$, and the air flow rate was $0.7 \mathrm{v} / \mathrm{v} /$ minute. The fermentation was terminated at 139 hours.

The fermentation medium for strain AB $1711 \mathrm{~J}-452$ consisted of glucose monohydrate $2.0 \%$, molasses (Del Monte) $0.5 \%$, Lexein F-1000 liquid peptone (Inolex) 1.0\%, whole yeast (Universal Foods) $0.5 \%$, $\mathrm{CaCO}_{3} 0.2 \%$ and $\mathrm{XFO}-371$ antifoam. The antifoam was added initially at $0.01 \%$ and then was available on demand. This medium was also prepared with distilled water with no $\mathrm{pH}$ adjustment. Fermentation was carried out in a 22 -liter vessel containing 15 liters of medium. The fermenter was inoculated with $750 \mathrm{ml}$ of seed flask growth. The temperature was controlled at $28^{\circ} \mathrm{C}$. The agitation rate was $250 \mathrm{rpm}$, and the air flow rate was $0.7 \mathrm{v} / \mathrm{v} /$ minute. The fermentation was terminated at 116 hours.

\section{Fermentation Analyses}

Cell growth was evaluated as packed cell volume by centrifuging the fermentation broth in a graduated conical tube at $600 \times g$ for 20 minutes. Residual carbohydrates were monitored by DuBors' phenol-sulfuric acid method ${ }^{9)}$. Dunaimycins were determined by an agar diffusion disk assay with Aspergillus niger ATCC 16404. Fermentation samples were prepared for bioassay by treating the whole culture broth with an equal volume of acetone.

\section{In Vitro Activity}

MICs of dunaimycins A1, C2, D2, D2S, D3 and D4S were determined by microtiter broth dilution methodology. Aerobic bacteria were tested in Brain Heart Infusion broth (Difco), anaerobes in Wilkins-Chalgren broth (Difco) and fungi in Yeast Nitrogen Base broth (Difco) containing $0.05 \%$ glucose. Tests were conducted with initial inocula of approximately $10^{4}$ to $10^{5} \mathrm{cfu} / \mathrm{ml}$. Aerobic bacteria and fungi were incubated 24 hours. Anaerobes were incubated for 48 hours.

\section{Results and Discussion}

\section{Taxonomy}

\section{Morphological and Chemical Characteristics}

Both strains produce branched vegetative hyphae typical of the order Actinomycetales. Each culture forms spores on flexuous chains which terminate in open spirals. Scanning electron microscopy of strain AB 1691Q-321 revealed that the spore surface is slightly wrinkled, and the spores have an average size of $1.2 \times 0.5 \mu \mathrm{m}$ (Fig. 1). Scanning electron micrograph of strain AB 1711 J-452 showed that the spore surface is smooth, and the spores have an average size of $1.0 \times 0.8 \mu \mathrm{m}$ (Fig. 2). Analysis of whole cell hydrolysates of $\mathrm{AB} 1691 \mathrm{Q}-321$ and $\mathrm{AB} 1711 \mathrm{~J}-452$ revealed the presence of LL-diaminopimelic acid in both cultures which indicates a type I cell wall ${ }^{10)}$.

+ ISCC-NBS Color-Name Charts Illustrated with Centroid Colors. U. S. Dept. of Comm. supp. to NBS Cir., 553, Washington, D.C., 1976. 
Fig. 1. Sporophore morphology of strain AB 1691Q321 from a 15 -day old culture grown on $1 / 20$ strength ISP 4 medium ( $1.5 \%$ agar) at $28^{\circ} \mathrm{C}$.

Bar represents $1 \mu \mathrm{m}$.

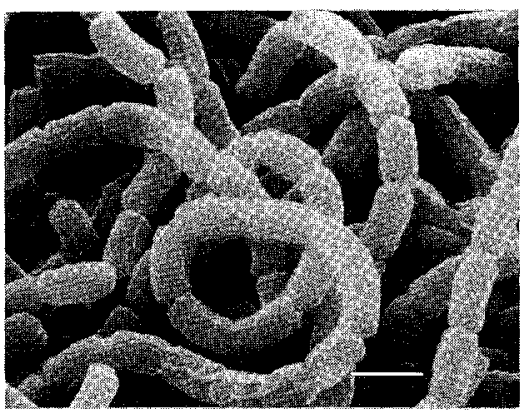

Fig. 2. Sporophore morphology of strain AB 1711J452 from a 10 -day old culture grown on ISP 4 medium at $28^{\circ} \mathrm{C}$.

Bar represents $1 \mu \mathrm{m}$.

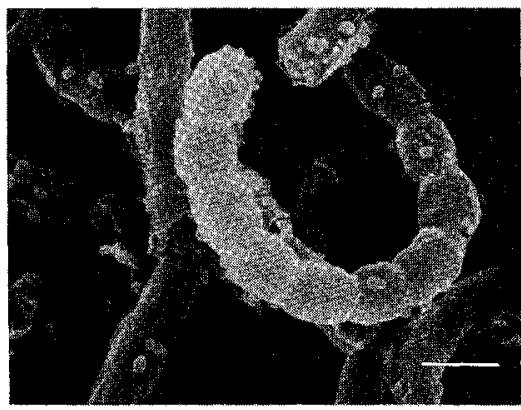

Table 1. Cultural characteristics.

\begin{tabular}{|c|c|c|c|}
\hline Medium & & Strain AB 1691Q-321 & Strain AB 1711J-452 \\
\hline \multirow{4}{*}{$\begin{array}{l}\text { Yeast extract - malt extract agar } \\
\quad \text { (ISP 2) }\end{array}$} & G: & Abundant, sporulated & Abundant \\
\hline & AM: & Light brownish gray $(63)^{\mathrm{a}}$ & Light gray (264) and black (267) \\
\hline & $\mathrm{R}:$ & Dark brown (59) & Dark orange yellow (72) \\
\hline & SP: & $\begin{array}{l}\text { Dark grayish yellowish brown } \\
(8 \mathrm{I})\end{array}$ & Grayish yellowish brown ( 80 ) \\
\hline \multirow[t]{4}{*}{ Oatmeal agar (ISP 3) } & $\mathrm{G}:$ & Abundant, sporulated & Moderate, partial aerial \\
\hline & AM: & Light brownish gray (63) & $\begin{array}{l}\text { Medium gray }(265) \text { and } \\
\text { black }(267) \text { coalescence }\end{array}$ \\
\hline & $\mathrm{R}:$ & Dark grayish yellow (91) & Dark gray $(266)$ \\
\hline & SP: & Absent & Absent \\
\hline \multirow{4}{*}{$\begin{array}{l}\text { Inorganic salts - starch agar } \\
\quad \text { (ISP 4) }\end{array}$} & $\mathrm{G}:$ & Abundant & Abundant \\
\hline & AM: & $\begin{array}{l}\text { Light gray (264) and } \\
\text { medium gray }(265)\end{array}$ & $\begin{array}{l}\text { Light gray (264) and } \\
\text { medium gray }(265)\end{array}$ \\
\hline & $\mathrm{R}:$ & Grayish reddish brown (46) & Grayish reddish brown (46) \\
\hline & SP: & Absent & Absent \\
\hline \multirow{4}{*}{$\begin{array}{l}\text { Peptone - yeast extract - iron agar } \\
\quad \text { (ISP 6) }\end{array}$} & G: & Moderate & Moderate \\
\hline & AM: & Absent & Absent \\
\hline & $\mathrm{R}:$ & Dark yellowish brown (78) & Dark grayish brown (62) \\
\hline & SP: & Brownish black $(65)$ & Brownish black $(65)$ \\
\hline \multirow[t]{4}{*}{ Tyrosine agar (ISP 7) } & $\mathrm{G}:$ & Abundant & Abundant; pocks in aerial mycelium \\
\hline & AM: & Light brownish gray (63) & $\begin{array}{l}\text { Light brownish gray (63) and } \\
\text { yellowish gray (93) }\end{array}$ \\
\hline & $\mathrm{R}:$ & Brownish black (65) & Brownish black $(65)$ \\
\hline & SP: & $\begin{array}{l}\text { Dark grayish yellowish brown } \\
\text { (81) }\end{array}$ & Brownish black (65) \\
\hline \multirow[t]{4}{*}{ ATCC 172 agar } & $\mathrm{G}:$ & Abundant & Abundant \\
\hline & AM: & Yellowish gray (93) & Absent \\
\hline & $\mathrm{R}$ : & Deep yellowish brown (75) & Moderate yellowish brown (77) \\
\hline & SP: & Dark yellowish brown (78) & Slight; dark yellowish brown (78) \\
\hline \multirow[t]{4}{*}{ DSYS agar } & G: & Moderate & Moderate \\
\hline & AM: & Light brownish gray (63) & Light gray (264) \\
\hline & $\mathrm{R}:$ & Yellowish gray (93) & $\begin{array}{l}\text { Yellowish gray (93); colony } \\
\text { centers are dark gray }(266)\end{array}$ \\
\hline & SP: & Absent & Absent \\
\hline
\end{tabular}

a Color and number in parenthesis follow ISCC-NBS Centroid Color Charts.

G: Growth, AM: aerial mycelium, R: reverse, SP: soluble pigment. 
Cultural and Physiological Characteristics

The cultural characteristics of strains AB 1691Q-321 and AB 1711J-452 are shown in Table 1. The mature, sporulated, aerial surface growth of both isolates is gray on all media tested. The cultures also produce soluble melanoid pigment on rich media. The carbon source utilization pattern of each is indicated in Table 2, and their physiological characteristics are shown in Table 3. The physiological characteristics are identical, but strain AB 1691Q-321 can utilize starch and sorbitol while AB 1711J-452 can not.

\section{Species Determination}

The morphology and type I cell wall of the dunaimycin producers place them in the genus Streptomyces. The 8th Edition of BERGEY's Manual $^{11)}$ and keys published by NonOmurA ${ }^{12)}$ and KURYŁowICZ et al. ${ }^{13)}$ were used to generate a list of species with similar characteristics. A comparison of our cultures with descriptions of these species suggested $S$. diastatochromogenes as the most appropriate assignment. The description of

Table 2. Utilization of carbon sources.

\begin{tabular}{lcc}
\hline & \multicolumn{2}{c}{ Growth } \\
\cline { 2 - 3 } Carbon source & AB $1691 \mathrm{Q}-321$ & AB 1711J-452 \\
\hline Arabinose & ++ & ++ \\
Cellulose & - & - \\
Fructose & ++ & ++ \\
Glucose & ++ & ++ \\
Inositol & ++ & ++ \\
Mannitol & ++ & ++ \\
Raffinose & ++ & ++ \\
Rhamnose & ++ & -+ \\
Sorbitol & + & + \\
Starch & + & ++ \\
Sucrose & ++ & ++ \\
Xylose & ++ & + \\
\hline
\end{tabular}

$++:$ Good utilization, + : poor utilization, - : did

Fig. 3. Time course of the dunaimycin fermentation by Streptomyces diastatochromogenes AB 1691Q-321 in a 150-liter fermenter.

$\triangle$ Growth, $\Delta \mathrm{pH}, \mathrm{O}$ total carbohydrate,

- dunaimycins.
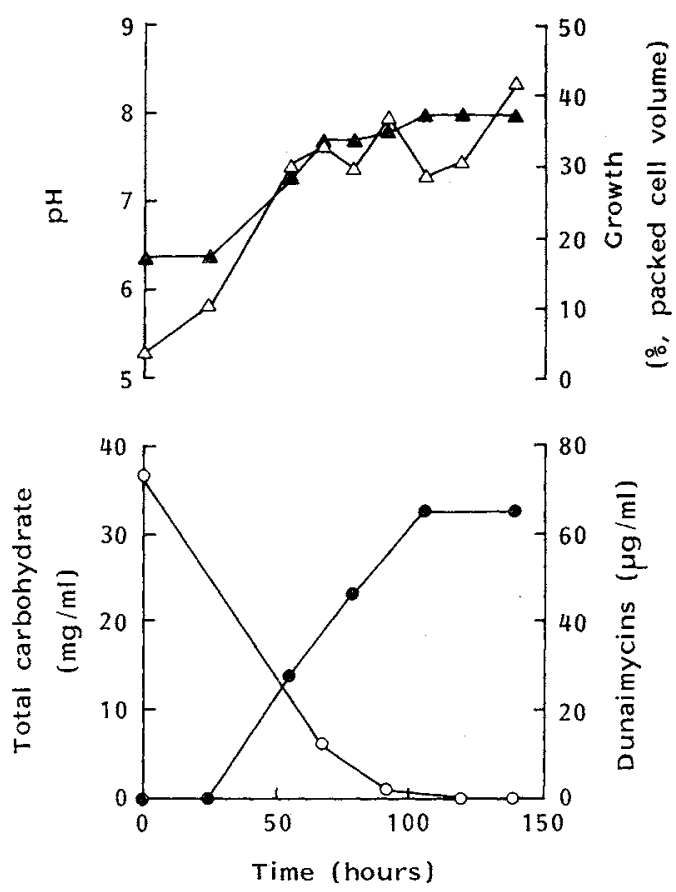

not utilize.

Table 3. Physiological characteristics.

\begin{tabular}{ccc}
\hline Test & AB $1691 \mathrm{Q}-321$ & AB $1711 \mathrm{~J}-452$ \\
\hline Melanin formation: & + & + \\
Peptone-yeast extract -iron agar & + & + \\
Tyrosine agar & + & + \\
Starch hydrolysis & + & + \\
$\mathrm{H}_{2} \mathrm{~S}$ production & $<4$ & $<4$ \\
NaCl tolerance (\%) & & Growth at 22 to $32^{\circ} \mathrm{C}$, \\
$\quad$ (yeast extract - malt extract agar) & Growth at 22 to $32^{\circ} \mathrm{C}$, & no growth at $42^{\circ} \mathrm{C}$ \\
Temperature range & no growth at $42^{\circ} \mathrm{C}$ & + \\
(yeast extract - malt extract agar) & + & \\
Nitrate reduction & \multicolumn{2}{c}{}
\end{tabular}


S. diastatochromogenes prepared by the International Streptomyces Project ${ }^{14)}$ is valid for AB 1691Q-321 and AB 1711J-452. Although quite similar, the two dunaimycin cultures vary in their gross appearance on some agar media and deviate slightly in their carbohydrate utilization patterns. These variations as well as differences in component production of the dunaimycins during fermentation encouraged us to regard them as separate strains of the same species. The latest edition of BERGEY's Manual ${ }^{15)}$ treats $S$. diastatochromogenes as a subjective synonym of $S$. diastaticus. We prefer to retain $S$. diastatochromogenes to recognize the melanin production of these cultures. Therefore, we have designated the dunaimycin producers $S$. diastatochromogenes AB 1691Q-321 and S. diastatochromogenes AB 1711J-452.

\section{Fermentation}

The time course of the production of the dunaimycins by strain AB 1691Q-321 is shown in Fig. 3. A maximum yicld of $65 \mu \mathrm{g} / \mathrm{ml}$ of the dunaimycins was reached at 105 hours. S. diastatochromogenes strain AB 1691Q-321 produces dunaimycins C1, C2, D2, D2S, D3 and D4S in fermentation. Strain AB 1711 J-452 produces dunaimycins A1, D2S and D3S.

\section{Antimicrobial Activity}

Table 4 indicates that the dunaimycins show only slight activity against bacteria. Table 5 indicates that the dunaimycins have modest activity against $A$. niger but are much less active against $C a n d i d a$ albicans and other yeasts.

Table 4. In vitro antibacterial activity of dunaimycins A1, C2, D2, D2S, D3 and D4S.

\begin{tabular}{lrrrrrr}
\hline \multicolumn{1}{c}{ Test microorganism } & \multicolumn{5}{c}{ MIC $(\mu \mathrm{g} / \mathrm{ml})$} \\
\cline { 2 - 6 } & $\mathrm{A} 1$ & $\mathrm{C} 2$ & $\mathrm{D} 2$ & $\mathrm{D} 2 \mathrm{~S}$ & $\mathrm{D} 3$ & $\mathrm{D} 4 \mathrm{~S}$ \\
\hline Staphylococcus aureus ATCC 6538P & $>8$ & 16 & 32 & 32 & $>8$ & 32 \\
S. aureus A5177 & 8 & 16 & 32 & 64 & $>8$ & 64 \\
Enterococcus faecium ATCC 8043 & 8 & $>128$ & 128 & 128 & $>8$ & 128 \\
Streptococcus pyogenes EES61 & 4 & 128 & 64 & 128 & $>8$ & 64 \\
Micrococcus luteus ATCC 4698 & 4 & 1 & 1 & 4 & 4 & 1 \\
Escherichia coli Juhl & $>64$ & $>128$ & $>128$ & $>128$ & $>64$ & $>128$ \\
Enterobacter aerogenes ATCC 13048 & $>64$ & $>128$ & $>128$ & $>128$ & $>64$ & $>128$ \\
Klebsiella pneumoniae ATCC 8045 & $>64$ & $>128$ & 128 & $>128$ & $>64$ & $>128$ \\
Pseudomonas aeruginosa A5007 & $>64$ & 128 & 64 & 128 & 64 & 128 \\
Acinetobacter calcoaceticus CMX 669 & 64 & 128 & 128 & $>128$ & 64 & 128 \\
Bacteroides fragilis ATCC 25285 & $>128$ & $>128$ & $>128$ & 64 & $>128$ & 64 \\
Clostridium perfringens ATCC 13124 & 16 & $>128$ & 64 & 64 & 32 & 128 \\
C. difficile ATCC 9689 & 32 & $>128$ & 32 & 64 & $>128$ & 64 \\
\hline
\end{tabular}

Table 5. In vitro antifungal activity of dunaimycins A1, C2, D2, D2S, D3 and D4S.

\begin{tabular}{lrrrrrr}
\hline \multirow{2}{*}{ Test microorganism } & \multicolumn{5}{c}{ MIC $(\mu \mathrm{g} / \mathrm{ml})$} \\
\cline { 2 - 7 } & A1 & C2 & D2 & D2S & D3 & D4S \\
\hline Candida albicans ATCC 10231 & 100 & $>100$ & $>100$ & 100 & 50 & 100 \\
C. albicans 579A & 100 & $>100$ & $>100$ & 100 & 50 & $>100$ \\
C. albicans ATCC 38247 & 100 & $>100$ & $>100$ & 100 & 50 & $>100$ \\
C. tropicalis NRRL-Y-112 & 100 & 100 & 100 & 100 & 100 & 100 \\
C. kefyr ATCC 28838 & $>100$ & $>100$ & $>100$ & $>100$ & 50 & $>100$ \\
C. glabrata ATCC 15545 & $>100$ & 100 & 100 & $>100$ & $>100$ & $>100$ \\
Cryptococcus albidus ATCC 34140 & $>100$ & $>100$ & $>100$ & 100 & 50 & 100 \\
Aspergillus niger ATCC 16404 & 25 & 6.25 & 12.5 & 6.25 & 25 & 6.25 \\
\hline
\end{tabular}




\section{Acknowledgments}

The authors are grateful to Dr. MAHLON Miller and Ms. Figen Seiler for electron microscopy and Ms. DeNa Hensey and Ms. Charlene VojtKo for antimicrobial evaluation.

\section{References}

1) Hochlowski, J. E.; M. M. Mullally, G. M. Brill, D. N. Whittern, A. M. Buko, P. Hill \& J. B. McAlpine: Dunaimycins, a new complex of spiroketal 24-membered macrolides with immunosuppressive activity. II. Isolation and elucidation of structures. J. Antibiotics 44: 1318 1330, 1991

2) Burres, N. S.; U. Premachandran, A. Frigo, S. J. Swanson, K. W. Mollison, T. A. Fey, R. A. Krause, V. A. Thomas, B. Lane, L. N. Miller \& J. B. McAlpine: Dunaimycins, a new complex of spiroketal 24-membered macrolides with immunosuppressive activity. III. Immunosuppressive activities of dunaimycins. J. Antibiotics 44: $1331 \sim 1341,1991$

3) Shirling, E. B. \& D. Gottlieb: Methods for characterization of Streptomyces species. Int. J. Syst. Bacteriol. 16: $313 \sim 340,1966$

4) KaRwowski, J. P.: The selective isolation of Micromonospora from soil by cesium chloride density gradient ultracentifugation. J. Indust. Microbiol. 1: $181 \sim 186,1986$

5) Gordon, R. E.; D. A. Barnett, J. E. Handerhan \& C. H. Pang: Nocardia coeliaca, Nocardia autotrophica, and the nocardin strain. Int. J. Syst. Bacteriol. 24: $54 \sim 63,1974$

6) Smibert, R. M. \& N. R. Krieg: General characterization. In Manual of Methods for General Bacteriology. Ed., P. GerhardT et al., pp. 409 443, American Society for Microbiology, 1981

7) KutzNer, H. J.: The family Streptomycetaceae. In The Prokaryotes. A Handbook on Habitats, Isolation, and Identification of Bacteria. Ed., M. P. STARR et al., pp. $2028 \sim 2090$, Springer-Verlag, 1981

8) Becker, B.; M. P. Lechevalier, R. E. Gordon \& H. A. Lechevalier: Rapid differentiation between Nocardia and Streptomyces by paper chromatography of whole-cell hydrolysates. Appl. Microbiol. 12: 421 423, 1964

9) Dubois, M.; K. A. Gilles, J. K. Hamllton, P. A. Rebers \& F. Smith: Colorimetric method for determination of sugars and related substances. Anal. Chem. 28: 350 356, 1956

10) Lechevalier, M. P. \& H. A. Lechevalier: Chemical composition as a criterion in the classification of aerobic actinomycetes. Int. J. Syst. Bacteriol. 20: 435 443, 1970

11) Pridham, T. G. \& H. D. Tresner: Genus I. Streptomyces Waksman and Henrici 1943, 339. In BergeY's Manual of Determinative Bacteriology. 8th Ed. Eds., R. E. BuCHANAN \& N. E. GibBons, pp. $748 \sim 829$, Williams \& Wilkins Co., 1974

12) NONOMURA, H.: Key for classification and identification of 458 species of the streptomycetes included in ISP. J. Ferment. Technol. 52: $78 \sim 92,1974$

13) Kuryeowicz, W.; A. Paszkiewicz, W. Wó́nicka, W. Kurzatkowski \& T. Szulga: Classification of streptomycetes by different numerical methods. In Numerical Taxonomy of Streptomycetes. Ed., W. KURYŁOWICZ et al., pp. $7 \sim 81$, Polish Medical Publishers, 1975

14) Shirling, E. B. \& D. GotTlieb: Cooperative description of type strains of Streptomyces. V. Additional descriptions. Int. J. Syst. Bacteriol. 22: 265 394, 1972

15) LocCl, R.: Section 29. Streptomycetes and related genera. In BERGEY's Manual of Systematic Bacteriology. Volume 4. Ed., S. T. WilliaMs et al., pp. 2451 2508, Williams \& Wilkins, 1989 